\title{
PERGESERAN ASAS LEGALITAS FORMAL KE FORMAL DAN \\ MATERIAL DALAM PEMBAHARUAN HUKUM PIDANA NASIONAL
}

\author{
Oleh \\ I Dewa Made Suartha \\ Fakultas Hukum Universitas Udayana \\ E-mail : dewa_suartha@yahoo.com
}

\begin{abstract}
Legality principle is a fundamental basis in the criminal law. The principle of legality which is in accordance with Penal Code Article 1 (1), the law stateskhat there are not any actions that are made into a punisment without first all, have any basis of the rule which passed the actions completely. There are so many actions based on customery law as deviant behaviours and should be made into a criminal case (custom delict), but law enforcement can not follow it up because they are contrary to formal legality. And if there are customery law (custom delict) which will be made into criminal case by the court is in accordance with statutes No. 1/Drtl1951, the finding of a court seems unfair fro conventional norms. In Penal Code renewal, the legislative assembly have taken notes of conventional norms. In Penal Code Concept formal legality principle which has been practiced in Wet Boek van Straf Recht (WvS) system has been softened or widened into legality principle of material.
\end{abstract}

Key words: legality principle, criminal law renewal.

\begin{abstract}
Abstrak
Asas legalitas merupakan asas yang sangat fundamental dalam hukum pidana. Asas legalitas yang tercantum dalam pasal 1 ayat (1) KUHP mutlak tunduk pada perinsip bahwa tidak ada suatu perbuaan yang dapat dipidana tanpa suatu dasar ketentuan undang-undang yang diadakan terlebih dahulu yang menetapkan dalam rumusan yang jelas dari perbuatan tersebut. Cukup banyak perbuatan yang menurut pandangan masyarakat sebagai perbuatan tercela dan patut dipidana (delik adat), akan tetapi penegak hukum tidak dapat menindak lanjutinya karena terbentur pada asas legalitas formal. Kalaupun ada di beberapa daerah delik adat diputus oleh pengadilan berdasarkan UU No. 1/Drt/1951, akan tetapi putusan pengadilan dirasakan tidak mencerminkan rasa keadilan masyarakat hukum adat. Dalam pembaharuan KUHP pembentuk undang-undang telah memperhatikan nilai-nilai hukum yang hidup dalam masyarakat. Dalam Konsep KUHP asas legalitas,(ormal yang selama ini dianut dalam sistem WvS (KUHP) telah diperlunak atau diperluas ke dalam asas legalitas materiel. Dengan perluasan asas legalitas maka pengadilan mempunyai landasan hukum untuk mengadili delik adat yang tidak ada bandingnya dalarrr KUHP.
\end{abstract}

Kata kunci : Asas legalitas, pembaharuan hukum pidana. 


\section{A. Pendahuluan}

Usaha pertama untuk mengadakan pembaharuan hukum pidana di Indonesia ialah dengan dikeluarkannya UU No. 1 Tahun 1946. Undangundang tersebut hendak menyesuaikan peraturan-peraturan pidana dengan keadaan waktu itu, sebelum pembentukan UU hukum pidana yang baru dapat dilakukan. Dengan dikeluarkannya UU No. 1 / 1946 adalah merupakan bagian dari politik hukum nasional, khususnya dalam bidang hukum pidana. Walaupun telah disesuaikan dengan perkembangan masyarakat dan keadaan Indonesia merdeka, akan tetapi jiwa KUHP (WvS) tersebut tetap kolonial karena didasarkan pada paham atau pandangan individualis libralistis. Keadaan yang demikian sudah jelas sangat bebeda dengan jiwa, pandangan hidup dan nilai-nilai budaya masyarakat Indonesia.

Salah satu asas pokok dalam hukum pidana adalah "asas legalitas” (principle of legality). Asas legalitas tersebut tercantum dalam pasal 1 ayat (1) KUHP, yang berarti setiap perbuatan yang disebut sebagai perbuatan/tindak pidana harus dirumuskan dalam undang-undang yang diadakan terlebih dahuhi yang menetapkan dalam rumusan yang jelas tentang perbuatan-perbuatan dimaksud. Sebagai konskwensinya, suatu perbuatan yang menurut pandangan masyarakat dianggap sebagai perbuatan tercela karena melanggar nilai-nilai hukum yang hidup dalam masyarakat tidak dapat dipindana karena tidak ditentukan secara tertulis dalam undang-undang. Dalam pembaharuan KUHP apabila tetap berpatokan pada asas legalitas formal, maka dalam implementasinya sudah barang tentu sangat dirasakan tidak mencerminkan rasa keadilan masyarakat.

Sebagaimana dikemukakan oleh Prof. Barda Nawawi Arief, bahwa dengan adanya ketentuan pasal 1 ayat (1) KUHP seolah-olah hukum pidana tidak tertulis yang hidup dalam masyarakat sengaja ditidurkan atau dimatikan. Ditidurkannya hukum pidana tidak tertulis pada jaman penjajahan masih dapat dimaklumi, karena memang sesuai dengan politik hukum Belanda saat itu. Namun akan sangat sangat dirasakan janggal apabila kebijakan itu juga diteruskan setelah kemerdekaan. Dengan adanya asas legalitas formal, hukum 
tidak tertulis / hukum yang hidup itu tidak pernah.tergali dan terungkap secara utuh kepermukaan, khsusnya dalam praktek peradilan pidana, (Barda Nawawi Arief, 2011 : 122 - 123). Oleh sebab itu dalam politik hukum nasional khtisusnya dalam usaha pembaharuan KUHP, adanya asas keseimbangan yaitu antara asas kepastian hukum dan asas keadilan sudah sewajarnya merupakan kebijakan formulatif dalam pembaharuan hukum pidana (criminal reform).

\section{B. Perlunya Pendekatan Nilai}

Pembaharuan hukum pidana tidaklah berarti hanya perubahan atau penyempurnaan terhadap ketentuan atau pasal-pasal dari KUHP sebagai sumber sentral dari hukum pidana, akan tetapi lebih daripada itu bahwa makna dan hakekat pembaharuan berkaitan erat dengan latar belakang dan urgensi diadakannya pembaharuan hukum pidana, yang dapat ditinjau dari aspek politis, filosofis dan kultural, atau juga dari berbagai aspek kebijakan yaitu kebijakan sosial, kriminal dan kebijakan penegakan hukum. Dengan demikian pembaharuan hukum pidana pada hakekatnya mengandung makna suatu upaya untuk melakukan reorientasi dan reformasi hukum pidana sesuai dengan nilai-nilai sentral sosio politik, sosio filosofis dan sosio kultural masyarakat Indonesia. (Barda Nawawi Arief, 12011 :30-31)

Dalam hubungan itu sangat relevan dikemukakan pandangan Prof. Koesnoe, bahwa selama ini studi hukum di Fakultas-Fakultas Hukum dan juga dalam praktek penegakan hukum (pidana) didasarkan pada hukum barat (WvS). Jadi hukum asing yang bukan hukum yang memuat nilai-nilai budaya kita sendiri yang lain daripada dasar-dasar filsafat, perasaan serta citacita hukum kita sendiri. Lebih jauh dikemukakan bahwa keadaan yang demikian sudah barang tentu akan membawa hal-hal yang dikemudian hari menimbulkan suasana tidak puas, dan untuk menghindari hal itu maka arah perhatian (dalam pendidikan hukum maupun kebijakan pembaharuan hukum pidana, pen.), perlu dititik beratkan pada apa yang nyaGa-nyata hidup, 
dihayati dan dijalani didalam lingkungan masyarakat hukum kita. (Moch. Koesnoe, 1991: 18).

Suatu KUHP harus mencerminkan nilai-nilai budaya suatu bangsa dimana KUHP itu berlaku. Sebab apa yang dianggap sebagai perbuatan tercela dan atau tidak boleh dilakukan sesuai dengan nilai-nilai dan pandangan masyarakat bangsa itu sendiri. Sebagaimana dikemukakan oleh Prof Sudarto, bahwa hukum pidana itu seharusnya merupakan pencerminan dari nilainilai budaya yang hidup dalam masyarakat yang bersangkutan. Hukum 'pidana sebagai sistem sanksi yang negatif memberi sanksi terhadap perbuatan-perbuatan yang tidak dikehendaki oleh masyarakat itu. Hal ini berhubungan dengan pandangan hidup tata susila dan moral keagamaan serta kepentingan bangsa yang bersangkutan. (Soekotjo hardiwinoto, 1995 : 2 - 3). Searah dengan pandangan tersebut Moh. Mahfud MD berpendapat bahwa hukum yang harus menjadi sentral itu tidak dapat dilepaskan dari masyarakatnya sebagai subyek yang akan dilayaninya, maka penyesuaian produk hukum dengan keadaan masyarakat menjadi sangat penting. Hukum yang tidak sesuai dengan realitas masyarakatnya atau bersumberkan dari paham asing akan sulit diterima dan diimplementasikan secara normal. (Mahfud, MD, 1977 : 18 -19).

Bertitik tolak dari kenyataan sosial dan pandangan para pakar tersebut diatas sudah sepatutnya dalam pembaharuan hukum pidana (KUHP), juga harus dilakukan dengan pendekatan nilai (value approach), yaitu nilai-nilai yang berlaku dalam masyarakat sekarang tentang apa yang tercela, yang tidak patut dalam pandangan masyarakat dan patut dipidana. Seperti ditegaskan dari Laporan Simposium Pembaharuan Hukum Pidana Nasional dalam salah satu butirnya disebutkan . " Masalah kriminalitas dan dekriminalisasi suatu perbuatan haruslah sesuai dengan politik kriminal yang dianut oleh bangsa Indonesia, yaitu sejauh mana perbuatan itu bertentangan dengan nilai-nilai fundamental yang berlaku dalam masyarakat dan oleh masyarakat dianggap patut atau tidak patut dihukum dalam rangka menyelenggarakan kesejahteraan masyarakat “. (Barda Nawawi Arief, 2011: 34). 
Dengan memahami ide, pola pikir dan norma-norma substantif KUHP yang didasarkan atas asas legalitas formal, secara dogmatis tidak mustahil dalam penerapannya terjadi perbenturan (konflik) dengan nilai-nilai dan kepentingankepentingan atau kebutuhan hukum yang ada dalam masyarakat. Adanya kesenjangan dan adanya perbedaan nilai atau kepentingan inilah akan dapat merupakan faktor timbulnya ketidak puasan dalam praktek penegakan hukum.

\section{Landasan Pembenaran Perluasan Asas Legalitas.}

Dalam pembaharuan hukum nasional salah satu kajian alternatif yang harus dikembangkan adalah kajian terhadap sistem hukum yang hidup dalam masyarakat. Dalam sistem hukum nasional disamping dapat menunjang pembangunan nasional dan kebutuhanpergaulan international, namun juga harus bersumber dan tidak mengabaikan nilai-nilai dan aspirasi hukum yang hidup dalam masyarakat.

Dalam pembaharuan KUHP Nasional (selanjutnya disebut Konsep KUHP) asas legalitas formal tetap dipertahankan akan tetapi Konsep juga memperluas perumusan secara materiel dengan memberi tempat pada hukum tidak tertulis (delik adat) sebagai sumber atau dasar hukum patut dipidananya suatu perbuatan. Sebagai dasar pembenaran perluasan asas legalitas formil kedalam perumusan secara materiel, dapat dikemukakan, beberapa alasan yang mendasarinya yaitu :

1. Landasan kebijakan legislatif nasional yang keluar setelah kemerdekaan, antara lain dikeluarkannya UU No. 1 / Drt/ 1951 dan UU No. 14 Tahun 1970 yo UU No. 35 Tahun 1999. Pasal 23 ayat (1) UU no. 14/1970 yo UU No. 35/1999, menentukan : “ segala putusan pengadilan ..........., harus memuat pula pasalpasal tertentu dari peraturan yang bersangkutan atau sumber hukum tidak tertulis : Dalam pasal 27 ayat (2), ditentukan : hakim sebagai penegak hukum dan keadilan wajib menggali, mengikuti dan memahami nilai-nilai hukum yang hidup.

2. Landasan kesepakatan ilmiah dalam seminarseminar nasional, yaitu : 
a. Resolusi Bidang Hukum Pidana Seminar Hukum Nasional ke I Tahun 1963:

1) Resolusi butir IV.

"Yang dipandang sebagai, perbuatan jahat itu adalah perbuatanperbuatan yang dirumuskan dalam KUHP, dst ........ Hal ini tidak menutup pintu bagi larangan perbuatan-perbuatan menurut hukum adat yang hidup dan tidak menghambat pembentukan masyarakat yang dicita-citakan, ......"

2) Resolusi butir VIII.

"Unsur-unsur hukum agama dan hukum adat dijalinkan dalam KUHP”

b. Laporan Seminar Hukum Nasional ke IV Tahun 1979.

Dalam Laporan sub. BII mengenai sistem hukum nasional, dinyatakan

1) Sistem hukum nasional harus sesuai dengan kebutuhan dan kesadaran hukum rakyat Indonesia. Hukum nasional sejauh mungkin diusahakan dalam bentuk tertulis. Disamping itu hukum yang tidak tertulis tetap merupakan bagian dari hukum nasional.

2) Hukum nasional dibina kearah unifikasi dengan memperhatikan kesadaran hukum masyarakat.

c. Laporan Simposium Pembaharuan Hukum Pidana Nasional Tahun 1980.

Dalam laporan angka II, antara lain dinyatakan : 1.5.1. .......... “ maka dalam proses pembaharuan tersebut haruslah melalui penelitian dan pengkajian yang mendalam tentang hukum pidana adat dan agama yang hidup dalam masyarakat Indonesia, dst. ....”.

1) Landasa sosiologis, yang bertolak dari budaya hukum kekeluargaan. Menurut Satjipto Rahardjo, budaya hukum kekeluargaan menghasilkan konsep "legalisme kekeluargan” dan konsep "the rule of justice / moral”.

2) Landasan internasional yang bertolak dari pasal 15 International Covenant on Civil and Political Rights (CCPR), yang menyebutkan 
adanya 2 (dua) dasar/sumber hukum untuk menyatakan perbuatan (si pembuat) dapat dipidana, yaitu :

a) berdasarkan UU atau hukum positif yang berlaku pada saat perbuatan dilakukan;

b) berdasarkan asas-asas atau perinsip-perinsip hukum umum yang diakui masyarakat bangsa-bangsa ("the general principle of law recognized by the community of nations "). (Barda Nawawi Arief, 2001: 51)

Pemikiran-pemikiran sebagaimana dipaparkan diatas merupakan landasan bagi Tim Penyusun Rancangan KUHP untuk memperluas asas legalitas formal kedalam perumusannya yang bersifat materiel.

\section{Implementasi Asas Legalitas Materiel dalam Rancangan KUHP}

Dalam Konsep KUHP Tahun 2014-2015, perumusan pasal 1 ayat (1) pada dasarnya sama dengan ketentuan yang terdapat dalam pasal 1 ayat (1) KUHP (WvS), yaitu tetap dianutnya asas legalitas formal. Dipertahankannya asas tersebut karena asas legalitas merupakan asas pokok dalam hukum pidana, untuk adanya kepastian hukum dan tidak adanya kesewenangwenangan penegak hukum dalam melakukan tindakan.

Memahami akan adanya tuntutan dan perkembangan masyarakat yang masih tetap mempertahankan nilai-nilai hukum yang hidup (delik adat) pada sebagian terbesar masyarakat Indonesia, dan jua perkembangan hukum dalam dunia internasional, maka agar aspirasi tersebut tertampung, penyusun Konsep KUHP mencantumkan ketentuan pasal 1 ayat (3), yang menentukan : “ Ketentuan sebagaimana dimaksud dalam ayat (1) tidak mengurangi berlakunya hukum yang hidup atau hukum adat yang menentukan bahwa menurut adat setempat seseorang patut dipidana walaupun perbuatan tersebut tidak diatur dalam perundangundangan “. Dalam ayat (4) ditentukan :“Terhadap perbuatan yang memenuhi ketentuan sebagaimana dimaksud dalam ayat (3) berlaku ketentuan pidana dalam pasal 93”.

Pasal 93 adalah pidana berupa "pemenuhan kewajiban adat”. Dalam penjelasan pasal 1 ayat (3) ditegaskan : 
“Adalah suatu kenyataan bahwa dalam beberapa daerah tertentu di Indonesia masih terdapat ketentuan hukum yang tidak tertulis yang hidup dan berlaku sebagai hukum di daerah tersebut. Hal yang demikian terdapat juga dalam lapangan hukum pidana yaitu yang biasanya disebut tindak pidana adat. Untuk memberikan dasar hukum yang mantap mengenai berlakunya hukum pidana adat, maka hal tersebut mendapat pengaturan yang tegas dalam KUHP- ini. Ketentuan dalam ayat ini merupakan pengecualian dari asas bahwa ketentuan pidana diatur dalam perundang-undangan. Diakuinya tindak pidana adat tersebut untuk lebih memenuhi rasa keadilan yang hidup didalam masyarakat tertentu”.

Dari ketentuan pasal 1 ayat (3) beserta penjelasannya tersebut telah menunujukkan bahwa Konsep telah memperluas asas legalitas dalam perumusannya yang bersifat materiel dengan mengakui eksistensi hukum yang hidup atau hukum adat sebagai sumber hukum positip, yang menjadi dasar patut dipidananya suatu perbuatan sepanjang perbuatan itu tidak ada persamaan atau bandingannya dalam Konsep. Dengan itu berarti dimungkinkannya penyimpangan terhadap asas lex certa sebagaimana diatur dalam asas legalitas yang dirumuskan dalam pasal 1 (ayat 1) Konsep. (Muladi, 1991 : 155).

Perluasan asas legalitas fomal dalam rumusannya yang bersifat materiel tidak dapat dilepaskan dari pokok pikiran untuk mewujudkan dan sekaligus menjamin asas keseimbangan antara kepentingan individu dan kepentingan masyarakat, dan antara kepastian hukum dan keadilan. Kepastian hukum adalah sebagai patokan formal sedangkan keadilan sebagai patokan materiel.

Dalam kasus-kasus tertentu dalam praktek peradilan mungkin nilai kepastian hukum dan nilai keadilan sama-sama mendesak. Apabila demikian, maka sebagaimana ditentukan pada pasal 16 Konsep, hakim sejauh mungkin mengutamakan keadilan diatas kepastian hukum.

Dengan perluasan asas legalitas dalam arti materiel, maka batas-batas tindak pidana juga diperluas, tidak saja apa yang tertulis secara formal dalam undang-undang, tetapi juga perbuatan-perbuatan yang menurut hukum yang 
hidup yang dipandang sebagai delik. Kriteria materiel ini juga diimplementasikan dalam pasal 15 Konsep, yang menentukan : “Untuk dapat dipidananya perbuatan yang dilarang dan diancam pidana oleh peraturan perundang-undangan perbuatan tersebut harus juga bersifat melawan hukum atau bertentangan dengan kesadaran hukum masyarakat”. Kemudian dalam ayat (3) ditentukan : "Setiap tindak pidana selalu dipandang bersifat melawan hukum, kecuali ada alasan pembenar”.

Dengan adanya ketentuan tersebut Konsep menganut paham melawan hukum materiel, yaitu tidak saja bertentangan dengan undang-undang tetapi juga dengan hukum tidak tertulis yaitu kesadaran hukum masyarakat. Penyusun Konsep dalam menentukan suatu perbuatan yang patut dipidana telah memperhatikan keselarasannya dengan perasaan hukum yang hidup dalam masyarakat, yaitu perbuatan itu tidak saja bertentangan dengan undang-undang tetapi juga selalu bertentangan dengan hukum.

Berkaitan dengan hal ini dalam pasal 51 ayat (1) Konsep ditentukan, bahwa dalam hal pemidanaan wajib dipertimbangkan antara lain bagaimana pandangan masyarakat terhadap tindak pidana yang dilakukan. Adanya ketentuan ini dimaksudkan agar putusan hakim betul-betul bersifat obyektif dapat mencerminkan rasa keadilan masyarakat, dan tidak semata hanya adil menurut pandangari hakim yang memutusnya.

\section{E. Simpulan}

Dari uraian sebagaimana telah dikemukakan dapat disimpulkan sebagai berikut :

1. Paham individualis libralistis yang mendasari sistem KUHP (WvS) sudah tidak sesuai lagi dengan konsep/pemikiran bangsa Indonesia yang lebih menekankan pada asas keseimbangan antara kepastian hukum dan keadilan, antara kepentingan individu dan masyarakat. Pemikiran dan pandanganpandangan agar memperhatikan nilai-nilai hukum yang hidup dalam masyarakat sebagai landasan dalam pembaharuan hukum pidana nasional sudah sering dikemukakan dalam pertemuan-pertemuan ilmiah, 
dan juga dilandasi oleh kebijakan legislatif dalam beberapa perundangundangan sejak jaman kemerdekaan.

2. Dalam Konsep KUHP,'asas legalitas formal yang selama ini dianut dalam sistem WvS, telah diperlunak atau diperluas kedalam asas legalitas yang bersifat materiel, dan telah diimplementasikan dalam ketentuan pasalpasalnya. Dengan perluasan asas legalitas berarti delik adat atau perbuatan-perbuatan yang melanggar nilai=nilai hukum yang hidup dalam masyarakat yang tidak ada ekivalensinya atau bandingannya dalam Konsep, dapat diproses dan diadili oleh pengadilan, sehingga dengan demikian adanya landasan hukum yang tegas dan jelas bagi penegak hukum dalam memeriksa dan mengadili delik adat.

\section{Daftar Pustaka}

Barda Nawawi Arief. 2011. Seberapa Aspek Kebijakan Penegakan dan Pengembangan Hukum Pidana, Bandung : PT Citra Aditya Bakti. .... 1996. Bunga Rampai Kebijakan Hukum Pidana. Bandung : PT Citra Aditya Bakti:

.... . 2001. Masalah Penegakan Hukum Dan Kebijakan Penanggulangan Kejahatan. Bandung : PT Citra Aditya Bakti.

H. Moch Koesnoe. 1991. Pemahaman dan Penggarapan Hukum Kodifikasi Dalam Kalangan Praktek dan Teori Hukum Kita Dewasa Ini. Surabaya : Universitas Bhayangkara.

Moh Mahfud MD. 1997. Pembaharuan Hukum Nasional Sebagai Amanat Proklamasi Dan Konstitusi. Jurnal Hukum No. 7 Vol. 4 / 1977. Universitas Islam Indonesia.

Muladi. 1990. Proyeksi Hukum Pidana Materiil Indonesia di Masa Mendatang (Pidato Pengukuhan). Fakultas Hukum Universitas Diponegoro Semarang.

Soekotjo Hardiwinoto. (penghimpun). 2005. Kumpulan Pidato Pengukuhan Guru besar Fakultas Hukum Universitas Diponegoro. Semarang.

Rancangan KUHP Tahun 2014-2015. Dirjen Hukum dan Perundang-undangan Departemen Hukum dan Perundangundangan. 